\title{
Penerapan Model Problem Based Learning (PBL) Berbasis Kontekstual Terhadap Peningkatan Kemampuan Berpikir Kritis Mahasiswa
}

\author{
Nurfathurrahmah \\ Program Studi Pendidikan Biologi, STKIP Bima. Jalan Piere Tendean Kel. Mande Tel. Fax \\ (0374) 42801, Bima 84191, Indonesia. \\ Email: fatuncampa87@gmail.com
}

\begin{abstract}
Abstrak
Tujuan penelitian adalah untuk mengetahui penerapan model Problem Based Learning (PBL) berbasis kontekstual terhadap peningkatan kemampuan berpikir kritis mahasiswa tahun akademik 2017/2018. Penelitain ini penelitian tindakan kelas (classroom action research) yang dilaksanakan dalam 2 siklus yang terdiri dari tahapan setiap siklus meliputi (1) perencanaan, (2) pelaksanaan tindakan, (3) observasi, (4) refleksi. Subyek penelitian 23 mahasiswa kelas II B program studi pendidikan biologi pada semester genap. Instrumen yang digunakan berupa soal tes kemampuan berpikir kritis diberikan dalam bentuk soal essay pretest-postest yang meliputi enam indikator yaitu mengklasifikasi, mengasumsi, memprediksi dan hipotesis, menginterpretasi data/membuat kesimpulan, mengevaluasi, menganalisis. Hasil penelitian menunjukkan kemampuan berpikir kritis mahasiswa pada setiap siklus pada saat pretest berada pada kategori sangat kurang kritis siklus I $(39,86)$, siklus II kategori kurang kritis $(58,30)$. Kategori kemampuan berpikir kritis mahasiswa meningkat pada postest seiring dengan peningkatan nilai yaitu siklus I 64,26 dikategorikan sedang sedangkan siklus II 75,52 dikategorikan kritis. Peningkatan dari pretest ke postest juga terlihat dari N-Gain (persentase peningkatan) menunjukkan siklus I 0,002 (2\%) dan siklus II 0,001 (1\%) peningkatan. Secara keseluruhan dapat disimpulkan terdapat $1 \%$ peningkatan yang terjadi dari siklus I ke siklus II meskipun masih dikategorikan rendah.
\end{abstract}

Kata kunci: Model Problem Based Learning (PBL) berbasis kontekstual, Berpikir kritis

\section{PENDAHULAUN}

Pendidikan yang mampu mendukung pembangunan di masa mendatang adalah pendidikan yang mampu mengembangkan potensi peserta didik, sehingga yang bersangkutan mampu menghadapi dan memecahkan problema kehidupan yang dihadapinya. Pendidikan harus menyentuh potensi nurani maupun potensi kompetensi peserta didik. Konsep pendidikan tersebut terasa semakin penting ketika seseorang harus memasuki kehidupan di masyarakat dan dunia kerja, karena yang bersangkutan harus mampu menerapkan apa yang dipelajari di sekolah untuk menghadapi problema yang dihadapi dalam kehidupan sehari-hari saat ini maupun yang akan datang (Trianto, 2010).

Uraian di atas sejalan dengan hasil observasi pada saat perkuliahan, mahasiswa lebih cenderung mempelajari fakta beserta teori berdasarkan hasil bacaan, penjelasan dari teman sejawat pada saat diskusi atau dosen yang menjelaskan materi perkuliahan tanpa disertai dengan fakta dan pembuktianyang terjadi di lapangan, kurangnya relevansi dari apa yang mereka pelajari dengan situasi di lingkungan hidup, kurang diberikan kesempatan untuk dapat membuka pikiran mahasiswa dalam kelas sehingga mereka tidak terbiasa memecahkan permasalahan yang ditemui dalam 
kehidupannya. Cakupan permasalah tersebut cukup beralasan yang dapat menghambat peningkatkan kemampuan berpikir secara kritis mahasiswa dalam belajar.

Fenomena yang terjadi pada saat perkuliahan, sejalan dengan fakta dilapangan yang cukup memprihatinkan, menurut Trianto (2010). Pertama, kebanyakan murid di sekolah tidak dapat membuat hubungan antara apa yang mereka pelajari dan bagaimana pengetahuan tersebut akan diaplikasikan. Kedua, murid-murid menghadapi kesulitan memahami konsep akademik (seperti konsep matematika) saat mereka diajar dengan metode tradisional, padahal mereka sangat perlu untuk memahami konsep-konsep saat mereka berhubungan dengan dunia kerja di mana mereka akan hidup. Ketiga, murid telah diharapkan untuk membuat sendiri hubunganhubungan tersebut, di luar kegiatan kelas.

Menurut Bahri (2017), salah satu penentu kualitas pendidikan adalah keberhasilan pendidikan pada pergurun tinggi. Strategi, model atau pola perkuliahan merupakan aspek penting dalam proses pendidikan selain materi untuk pencapaian kompetensi. Pengalaman belajar yang diperoleh mahasiswa selama perkuliahan berlangsung sangat berperan dalam pembentukan kemampuan dan menentukan kualitas dari perkuliahan.

Oleh karena itu, dosen memiliki tanggung jawab membentuk pengalaman belajar mahasiswa salah satunya melalui penggunaan strategi pembelajaran yang tepat. Permasalahan yang ada dan pernyataan yang mendukung, memungkinkan peneliti untuk menerapkan model Problem Based Learning (PBL) berbasis kontekstual.

\section{Model Problem Based Learning}

(PBL), pembelajaran berdasarkan masalah juga melatih siswa untuk dapat menjawab pertanyaan terbuka dengan banyak alternatif jawaban benar yang pada akhirnya akan meningkatkan kemampuan berpikir kritis siswa dan mampu meningkatkan pemahamannya serta menjadikannya sebagai siswayang mandiri (Asniar, 2011). Sedangkan Contextual Teaching and Learning (CTL) merupakan proses pembelajaran yang holistik dan bertujuan membantu peserta didik untuk memahami makna materi ajar dengan mengaitkannya terhadap konteks kehidupan mereka sehari-hari (konteks pribadi, sosial dan kultural), sehingga siswa memiliki pengetahuan/keterampilan yang dinamis dan fleksibel untuk mengkontruksi sendiri secara aktif pemahannya (Yamin, 2013).

Hassoubah (2002) dalam Yogihati (2010), berpikir kritis merupakan kegiatan menganalisis ideatau gagasan ke arah yang lebih spesifik, membedakan secara tajam, memilih, mengidentifikasi, mengkaji dan mengembangkannya ke arah yang lebih sempurna.

Kategori berpikir kritis menurut Carvin dan Sund (1998) dalam Dwijayanti. P dan Yulianti. D (2010), 
yaitu 1) mengklasifikasi, 2) mengasumsi, 3) memprediksi dan hipotesis, 4) menginterpretasi data, mengiferensi atau membuat kesimpulan, 5) mengukur, 6) merancang sebuah penyelidikan, 7) mengamati, 8) membuat grafik, 9) meminimalkan kesalahan percobaan, 10) mengevaluasi, 11) menganalisis.

Materi vegetasi merupakan salah satu materi pada mata kuliah ekologi tumbuhan yang diajarkan pada mahasiswa pendidikan biologi semester II. Pemilihan materi vegetasi melalui penerapan model Problem Based Learning (PBL) berbasis kontekstual terhadap peningkatan kemampuan berpikir kritis mahasiswa dirasa tepat, dikarenakan kegiatan pembelajaran yang menekankan untuk dikaitkan dengan situasi nyata, sehingga mengakomodasi keterlibatan siswa dalam belajar dan pemecahan masalah otentik, dimana pendidik menyajikan masalah yang otentik dan bermakna dalam bentuk pertanyaan ataupun pernyataan secara tertulis yang dapat memberikan kemudahan pada siswa untuk melakukan penyelidikan dan inkuiri. Oleh sebab itu kemampuan berpikir kritis sangat diperlukan dalam pemecahan masalah atau pencarian solusi. Sehubungan dengan hal tersebut penulis melakukan penelitian penerapan model Problem Based Learning (PBL) berbasis kontekstual terhadap peningkatan kemampuan berpikir kritis mahasiswa tahun akademik 2017/2018.
Berdasarkan latar belakang yang diuraikan, maka masalah yang akan diteliti dalam penelitian ini: Bagaimanakah penerapan model Problem Based Learning (PBL) berbasis kontekstual terhadap peningkatan kemampuan berpikir kritis mahasiswa tahun akademik 2017/2018.? Tujuan penelitian adalah sebagai berikut untuk mengetahui penerapan model Problem Based Learning (PBL) berbasis kontekstual terhadap peningkatan kemampuan berpikir kritis mahasiswa tahun akademik 2017/2018.

\section{METODE}

Penelitian ini adalah penelitian tindakan kelas (classroom action research) dengan tahapan-tahapan meliputi (1) perencanaan, pelaksanaan tindakan, (3) observasi, (4) refleksi, yang selanjutnya tahapan tahapan tersebut dirangkai dalam dua siklus kegiatan. Pendekatan dalam penelitian adalah kualitatif deskriptif. Penelitian dilaksanakan mulai bulan April sampai Mei 2018, pada kelas II B dengan subjek penelitian 23 mahasiswa program studi pendidikan biologi semester genap.

Instrumen yang digunakan dalam penelitian ini adalah soal tes. Kemampuan berpikir kritis diberikan dalam bentuk soal essay, dilakukan pada pertemuan kedua tiap siklus. Penelitian ini difokuskan untuk mengembangkan kemampuan berpikir yang meliputi mengklasifikasi,

mengasumsi, 
memprediksi dan hipotesis, membuat kesimpulan, mengevaluasi, menganalisis. Teknik pengumpulan data dalam penelitian ini adalah berupa data kemampuan berpikir kritis diperoleh melalui pemberian soal essay sebanyak 5 nomor yang terdiri dari 6 indikator kemampuan berpikir kritis. Data hasil belajar siswa digunakan untuk mengetahui kemampuan berpikir kritis

Tabel 1. Kategori Kemampuan Berpikir Kritis

\begin{tabular}{|c|c|}
\hline Rentang Nilai & Kategori \\
\hline $40,00-51,40$ & Sangat Kurang kritis \\
$51,41-62,90$ & Kurang kritis \\
$62.91-74,30$ & Sedang \\
$74,31-85,70$ & Kritis \\
$\geq 85,71$ & Sangat kritis \\
\hline
\end{tabular}

(Sumber: Jufri dan Sulistya, 2010).

\section{HASIL DAN PEMBAHASAN}

Hasil penelitian kemampuan berpikir kritis pada siklus I dan siklus II mahasiswa kelas B semester II tahun akademik 2017/2018 pada materi vegetasi, diperoleh melalui pemberian soal tes berupa pretest dan postest dari pretest-postest siklus I ke pretestpostest siklus II. Data yang diperoleh dari tes kemampuan berpikir kritis dianlaisis secara kuantitatif dengan persentase. Penilaian ini dilakukan berdasarkan skor mulai 0 sampai 5, kemudian diakumulasi, serta dinyatakan dalam 5 kategori menurut Grounlun dan Linn (1990) sebagai berikut:

Tabel 2. Ringkasan Hasil Perhitungan Data Kemampuan Berpikir Kritis Setiap Siklus

\begin{tabular}{|l|c|c|c|c|}
\hline \multirow{2}{*}{ Komponen } & \multicolumn{2}{c|}{ Siklus } & \multicolumn{2}{c|}{ Kategori } \\
\cline { 2 - 5 } & Siklus I & Siklus II & Siklus I & Siklus II \\
\hline \multirow{2}{*}{ Jumlah pretest } & 39,86 & 58,30 & $\begin{array}{c}\text { Sangat } \\
\text { Kurang } \\
\text { Kritis }\end{array}$ & $\begin{array}{c}\text { Kurang } \\
\text { kritis }\end{array}$ \\
\hline Jumlah postest & 64,26 & 75,52 & Sedang & Kritis \\
\hline$\%$ pretest & 0,39 & 0,58 & & \\
\hline$\%$ postest & 0,64 & 0,75 & & \\
\hline Rata-rata pretest & 1,73 & 2,53 & & \\
\hline Rata-rata postest & 2,79 & 3,28 & & \\
\hline$\%$ postest-\% pretest & 0,24 & 0,17 & & Rendah \\
\hline$\%$ maks -\% pretest & 99,60 & 99,41 & & \\
\hline N-Gain & 0,002 & 0,001 & Rendah & \\
\hline $\begin{array}{l}\text { N-Gain (\% peningkatan siklus I ke } \\
\text { siklus II) }\end{array}$ & \multicolumn{2}{|c|}{$0,01 \%$} & Rendah & \\
\hline
\end{tabular}

Melengkapi dan memperjelas

data di atas, maka dilakukan 
perhitungan berdasarkan indikator diuraikan dalam tabel 3 berikut ini.

kemampuan berpikir kritis yang

Tabel 3. Jumlah Total Data Kemampuan Berpikir Kritis Berdasarkan Indikator Kemampuan Berpikir Kritis

\begin{tabular}{|l|c|c|c|c|}
\hline \multirow{2}{*}{\multicolumn{1}{|c|}{ Indikator berpikir kritis }} & \multicolumn{2}{c|}{ Siklus I } & \multicolumn{2}{c|}{ Siklus II } \\
\cline { 2 - 5 } & Pretest & postest & Pretest & Postest \\
\hline Menganalisis & 53 & 102 & 62 & 96 \\
\hline Mengklasifikasi & 38 & 81 & 55 & 84 \\
\hline Mengevaluasi & 28 & 64 & 51 & 82 \\
\hline Memprediksi dan hipotesis & 31 & 56 & 54 & 83 \\
\hline Mengasumsi & 35 & 63 & 57 & 81 \\
\hline $\begin{array}{l}\text { Menginterpretasi } \\
\text { data/menyimpulkan }\end{array}$ & 40 & 61 & 57 & 73 \\
\hline Rata-rata & 37,5 & 71,16 & 56 & 83,16 \\
\hline
\end{tabular}

Peningkatan kemampuan berpikir kritis pada hasil perolehan pretest dan postest mahasiswa per indikator dihitung menggunakan $N$-Gain untuk melihat dan tiap indikator. Perhitungan tersebut ditampilkan dalam tabel 4. memastikan persentase peningkatannya

Tabel 4. Hasil Perhitungan N-Gain Data Kemampuan Berpikir Kritis Berdasarkan Indikator Kemampuan Berpikir Kritis

\begin{tabular}{|l|c|c|c|c|}
\hline \multirow{2}{*}{\multicolumn{1}{|c|}{ Indikator berpikir kritis }} & \multicolumn{2}{c|}{ N-Gain } & \multicolumn{2}{c|}{ Kategori } \\
\cline { 2 - 5 } & Siklus I & Siklus II & Siklus I & Siklus II \\
\hline Menganalisis & 0,10 & 0,07 & Rendah & Rendah \\
\hline Mengklasifikasi & 0,11 & 0,08 & Rendah & Rendah \\
\hline Mengevaluasi & 0,09 & 0,08 & Rendah & Rendah \\
\hline Memprediksi dan hipotesis & 0,06 & 0,08 & Rendah & Rendah \\
\hline Mengasumsi & 0,07 & 0,06 & Rendah & Rendah \\
\hline Menginterpretasi data/menyimpulkan & 0,05 & 0,04 & Rendah & Rendah \\
\hline
\end{tabular}

Data hasil perhitungan $N$-Gain menunjukkan bahwa nilai peningkatan kemampuan berpikir kritis siklus I tertinggi terjadi pada indikator mengklasifikasi sebesar $0,11(11 \%)$ berada pada kategori rendah, sedangkan pada siklus II tertinggi berada pada indikator mengklasifikasi, mengevaluasi dan memprediksi dan hipotesis sebesar 0,08 (8\%) berada pada kategori rendah. Walaupun dikategorikan rendah tetapi secara angka menunjukkan peningkatan. 
Penerapan model problem based indikator mengklasifikasi, mengevaluasi, learning berbasis kontekstual dalam penelitian memprediksi dan hipotesis sebesar $8 \%$. ini mampu meningkatkan kemampuan berpikir Peningkatan yang terjadi tidak terlepas dari kritis mahasiswa pada materi vegetasi adanya tindakan refleksi yang dilakukan untuk semester II B tahun akademik 2017/2018, hal memperbaiki kekurangan pada siklus I yaitu: ini terbukti dari hasil analisis data pada siklus I pendidik lebih mengarahkan mahasiswa untuk nilai pretest-postest mengalamai peningkatan sampai pada siklus II, terlihat dari N-Gain (persentase peningkatan) menunjukkan siklus I $0,002(2 \%)$ dan siklus II 0,001 (1\%). Secara keseluruhan dapat disimpulkan terdapat $1 \%$ peningkatan yang terjadi dari siklus I ke siklus II meskipun masih dikategorikan rendah. Data tersebut diperkuat melalui analisis secara indikator kemampuan berpikir kritis ditunjukkan adanya peningkatan nilai rata-rata pretest-postest yaitu siklus I (pretest 37,5)(postest 71,16), siklus II (pretest 56)-(postest 83,16). Indikator yang paling tinggi peningkatannya pada siklus I adalah indikator menganalisis yaitu jumlah nilai pretest 53 meningkat pada nilai postest 102 sedangkan pada siklus II nilai pretest 62 meningkat menjadi 96 pada nilai postest. Secara persentase peningkatan dari kesuruhan nilai pretest dan postest pada masing-masing siklus berdasarka enam indikator kemampuan berpikir kritis ditunjukkan N-Gain masih dikategorikan rendah akan tetapi secara angka mengalami peningkatan, terutama pada siklus I indikator mengklasifikasi sebesar $11 \%$ sedangkan pada siklus II tertinggi pada lebih termotivasi dalam mengasah kemampuan berpikir kritis serta mengkonstruksi sendiri pengetahuannya, mengevaluasi pemahaman setiap mahasiswa melalui menanyakan kesulitan dan pemahaman siswa terhadap tugas yang dikerjakan.

Hasil yang diperoleh menunjukkan bahwa model problem based learning memiliki peranan penting dalam meningkatnya kemampuan berpikir kritis. Hal ini disenada dengan pendapat Ratumanan (2002) dalam Trianto (2010) bahwa pengajaran berdasarkan masalah merupakan pendekatan yang efektif untuk pengajaran proses berpikir tingkat tinggi, membantu siswa untuk memproses informasi yang sudah jadi dalam benaknya dan menyusun pengetahuan mereka sendiri tentang dunia sosial dan sekitarnya, pembelajaran ini cocok untuk mengembangkan pengetahuan dasar maupun kompleks. Penelitain Asniar (2011) juga mendukung pencapaian dalam penelitian ini, dalam penelitiannya menyatakan bahwa pembelajaran berdasarkan masalah juga melatih siswa untuk dapat menjawab pertanyaan terbuka dengan banyak alternatif jawaban benar yang pada akhirnya 
akan meningkatkan kemampuan berpikir kritis siswa dan mampu meningkatkan pemahamannya serta menjadikannya sebagai siswa yang mandiri.

Pencapaian peningkatan kemampuan berpikir kritis mahasiswa tidak terlepas dari usaha pendidik dalam menerapkan model pembelajaran dengan baik, selain didukung oleh model pembelajaran faktor lain yang mendukung tercapainya tujuan dalam penelitian ini adalah faktor pemilihan materi vegetasi. Karena cakupan materi vegetasi sangat luas dan sangat cocok diterapkan melalui model problem based learning berbasis kontekstual. Dalam uraian materi vegetasi sangat cocok dengan kodisi nyata (kontekstual) yang sering ditemui bahkan dialami oleh mahasiswa sebagai subyek peneltian, serta soal-soal untuk mengasah kemapuan berpikir kritis mahasiswa disusun berdasarkan permasalah yang sesuai dengan situasi nyata dalam lingkungan kehidupannya. Hal ini sejalan dengan Trianto (2010) dalam (US Departement of Education the National School-to-Work office yang dikutip oleh Blanchard (2001), menyatakan pengajaran dan pembelajaran kontekstual atau contextual teaching and learning (CTL) merupakan suatu konsepsi yang membantu guru mengkaitkan konten mata pelajaran dengan situasi dunia nyata dan momotivasi siswa membuat hubungan antara pengetahuan dan penerapannya dalam kehidupan mereka sebagai anggota keluarga, warga negara, dan tenaga kerja.

Selain dari pada itu adanya kelebihan dalam menerapkan berpikir kritis melibatkan keahlian berpikir induktif seperti mengenali hubungan, manganalisis masalah yang bersifat terbuka, menentukan sebab dan akibat, membuat kesimpulan dan memperhitungkan data yang relevan. Sedang keahlian berpikir deduktif melibatkan kemampuan memecahkan masalah yang bersifat spasial, logis silogisme dan membedakan fakta dan opini.Keahlian berpikir kritis lainnya adalah kemampuan mendeteksi bias, melakukan evaluasi, membandingkan dan mempertentangkan, Gunawan (2003) dalam Nengah (2013).

\section{KESIMPULAN}

Berdasarkan hasil analisis data dan pembahasan, maka dapat disimpulkan bahwa melalui penerapan model problem based learning berbasis kontekstual terdapat peningkatan kemampuan berpikir kritis mahasiswa pada materi vegetasi semester II B tahun akademik 2017/2018.

\section{DAFTAR PUSTAKA}

Asniar, H. (2011). Pengembangan Perangkat Pembelajaran Biologi Berbasis Masalah Pada Materi Kerusakan Dan Pencemaran Lingkungan Kelas X. Tesis. Tidak diterbitkan: PPs Universitas Negeri Makassar. 
Bahri, A. (2017). Strategi Problem Based Learning (PBL) Terintegrasi Reading Questioning And Answering (RQA) Meningkatkan Retensi Mahasiswa Berkemampuan Akademik Berbeda. Jurnal. Diakses pada tanggal 19 Maret 2018.

Dwijayanti. P, Yulianti. D. (2010). Pengembangan Kemampuan Berpikir Kritis Mahasiswa Melalui Pembelajaran Problem Based Instruction Pada Mata Kuliah Fisika Lingkungan. Semarang: Jurnal Pendidikan Fisika Indonesia 6 (2010) 108-114. Diakses pada tanggal 19Maret 2018.

Jufri, A.W., dan Sulistyo, D.J. (2010). Efektivitas Pembelajaran Sains Berbasis Inkuiri dengan Strategi
Kooperatif dalam Meningkatkan Keterampilan Berpikir Siswa SMP. Jurnal Pendidikan dan Pembelajaran Volume 17 Nomor 2 Oktober 2010.

Nengah. (2013). Apa Itu Berpikir Kritis. (online):http://nengah235.blogspot.co.i d/2013/03/apa-itu-berpikir-

kritis.html.di akses pada taggal 19 Maret 2018.

Trianto. (2010). Mendesain Model Pembelajaran Inovatif-Progresif (Konsep, Landasan, dan Implementasi KTSP). Jakarta: Kencana Prenada Media Group.

Yamin. (2013). Paradigma Baru Pembelajaran. Jakarta: Referensi. 